\title{
Protective Effect of Propolis against Aluminium Chloride Reproductive Ultrastruchtural Study Histopathological and
}

By Essam Eldin Abdelhady Salama King Saud University

Abstract- Human impact on the environment was steadily increasing the amounts of aluminum in the ecosystems. This element accumulated in plants and water. Potentially increased its harmful effect; particularly, it induced free radical-mediated cytotoxicity and reproductive toxicity. Propolis was a resinous material collected by bees from bud and exudates of the plants, mixed with bee enzymes, pollen, and wax. Due to its waxy nature and mechanical properties, bees used propolis in the construction and repair of their hives, and as a protective barrier against external invaders, or weathering threats, Current antimicrobial properties of propolis, was helping for wound healing, treatment of burns, herpes simplex and genital herpes. The present work studied the protective effect of propolis against the reproductive toxicity of aluminum chloride in male rats.

Keywords: male albino rat. Aluminum chloride toxicity. Propolis.

GJMR-G Classification: NLMC Code: QW 70

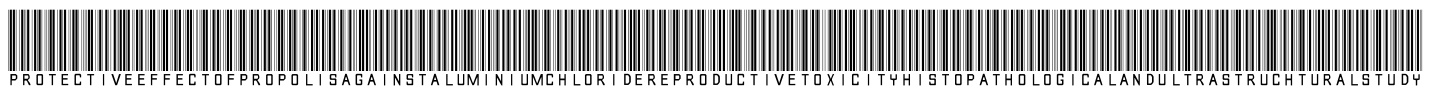

Strictly as per the compliance and regulations of:

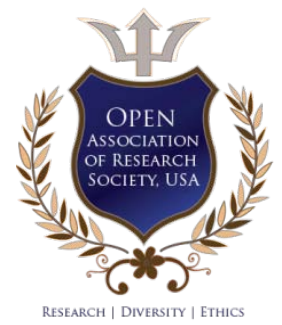

(c) 2020. Essam Eldin Abdelhady Salama. This is a research/review paper, distributed under the terms of the Creative Commons Attribution-Noncommercial 3.0 Unported License http://creativecommons.org/licenses/by-nc/3.0/), permitting all non-commercial use, distribution, and reproduction in any medium, provided the original work is properly cited. 


\title{
Protective Effect of Propolis against Aluminium Chloride Reproductive Toxicity Histopathological and Ultrastruchtural Study
}

\author{
Essam Eldin Abdelhady Salama
}

\begin{abstract}
Human impact on the environment was steadily increasing the amounts of aluminum in the ecosystems. This element accumulated in plants and water. Potentially increased its harmful effect; particularly, it induced free radicalmediated cytotoxicity and reproductive toxicity. Propolis was a resinous material collected by bees from bud and exudates of the plants, mixed with bee enzymes, pollen, and wax. Due to its waxy nature and mechanical properties, bees used propolis in the construction and repair of their hives, and as a protective barrier against external invaders, or weathering threats, Current antimicrobial properties of propolis, was helping for wound healing, treatment of burns, herpes simplex and genital herpes. The present work studied the protective effect of propolis against the reproductive toxicity of aluminum chloride in male rats.
\end{abstract}

Material and Methods: Sixty male Wistar Albino rats (average weight $200 \mathrm{~g}$ ) were used and divided into three groups; each contained twenty rats. Groupe I, was a control group, group II, was treated with aluminum chloride ( $80 \mathrm{mg} / \mathrm{Kg}$. body weight) through an orogastric tube, daily for six weeks. Group III, was given aluminum chloride (80 mg / Kg. body weight), concomitant with (200 mg / Kg. body weight) ethanol extract of propolis, for the same root and period.

Results: Study of the second group revealed degeneration and necrosis of the seminiferous tubules, as demonstrated with the light microscope. The ultrastructure study revealed dilated irregular tubular membrane, Sertoli cell, spermatogonia, and early spermatid with vacuolated cytoplasm and irregular nuclei, swollen mitochondria, dilated irregular tubular membrane. Apparent improve in the light and ultrastructure study of the third group. The results concluded the administration of aluminum chloride to adult male rats would cause adverse effects on reproductive efficiency that could be overcome by the protective effect of propolis.

Objective: Of our results would suggest that propolis would provide a therapeutic value against aluminum-induced male reproductive toxicity.

Keywords: male albino rat. Aluminum chloride toxicity. Propolis.

\section{INTRODUCTION}

A luminum was widely spread in our environment. It was the third most abundant element on the earth's crust [1]. It has no known biological role in living organisms and may be classified as toxic metal [2]. It was widely used for the manufacturing of many

Author: Department of Anatomy and Embryology, Faculty of Medicine, King Saud University, Riyadh, Kingdom of Saudi Arabia Al Azhar University, Cairo, Egypt. e-mail: essamco58@gmail.com products [1]. And as a result, food consumption was the major source for aluminum intake under physiological conditions [3]. The widespread presence of aluminum, both in the environment and in food, made it almost impossible to avoid exposure to this metal ion [4]. Aluminum -containing diet was mainly corn, yellow cheese, salts, herbs, spices, and tea, [5]. It entered in production of cosmetics such as antiperspirant and deodorant preparation [6]. Moreover, it incorporated in some medications such as antacids, buffered aspirin, antidiarrheal products, vaccine, and allergen injection [7], [8], and [9]. Also, it used as a component of veterinary medicine, glues, and disinfectants [10]. Aluminum sulfate added as a coagulant agent during the purification process of drinking water [11]. Recently, Aluminum in drinking water led to the development of many diseases and health problems [1]. Aluminum chloride was suggested to induced reproductive toxicity and exerted a significant adverse effect on steroidogenesis [12]. Aluminum compound had serious effects on energy metabolism and hematology [13], [14]. It enhanced free radicals, and changed the enzymatic activities [15], with emphasis on the alterations in the metabolism of testis, epididymis and vas deferens that led to poor sperm motility and reduction in fertility rate in mice [16],[17]. It reduced fertility and reproductive activity [18],[19], and also affected the process of development of embryos by its embryotoxicity and teratogenicity [20]. Liobet et al. [21], Khattab [22], Guo et al. [23], and Fairoze [24]; observed histological changes including necrosis of spermatocytes and spermatids in the testis of male mice treated with aluminum nitrate, and degeneration in the structure of spermatogenesis and formation of giant cells in mice testis treated with aluminum chloride, severe damage within seminiferous tubules and vascular degeneration on spermatogenic and Sertoli cells cytoplasm.

Propolis was a natural resinous mixture produced by honeybees from substances collected from parts of plants, buds, and exudates. Due to its waxy nature and mechanical properties, bees used propolis in the construction and repair of their hives, sealing openings, and cracks, smoothing out the internal walls, and as a protective barrier against external invaders like snakes, lizards, winds and rains 
[25], [26]. It possessed a characteristic and pleasant aromatic smell and various colors from transparent propolis, yellow, green, red, or dark brown, depending on the site of origin, source, and age of the resins, it was hard and brittle, and became soft, pliable, gummy, and very sticky when heated [27]. Raw propolis was composed of around 50\% resins, 30\% waxes, $10 \%$ essential oils, $5 \%$ pollen, and $5 \%$ of various organic compounds [28], [29], and [30]. Propolis was soft, pliable, and sticky substance at $25 \circ \mathrm{C}$ to $45 \circ \mathrm{C}$, above $45 \circ \mathrm{C}$; it became gummy, and liquid at $60 \circ \mathrm{C}$ to $70 \circ \mathrm{C}$, but for some samples the melting point might be as high as $100 \circ C$ [27]. Propolis was extracted with a suitable solvent, the most common solvents used for extraction were water, ethanol, methanol, chloroform, ether, and acetone [31]. According to Ugur and Arslan [32], the use of different solvents changed the biological activity of the main active constituent in propolis. The aqueous extract of propolis showed higher antioxidant activity compared to the ethanol extract of propolis; this was due to its higher polyphenols content. So, it used in prevention of various free radical related diseases. Ethanolic extracts of propolis showed high antibacterial activity against Gram-positive, but least activity against Gram-negative bacteria [33], [34]. Selvan et al. [35] reported that bee propolis, in combination with chlorhexidine, possessed high antimicrobial activity against streptococcus mutants. Propolis was the bee product with the highest antifungal activity as tested with 40 yeast strains of C. Albicans [36],[37]. Propolis showed fungicide effects that prevented juice spoilage [38]. According to Dota et al. [39]. The propolis extract had fungicidal effect against clinical yeas, and also for of the vulvovaginal candidiasis. The European propolis cured some human diseases caused by protozoa [40],[41] and [42]. Propolis was known for its antioxidant properties [43], [44]. The antioxidants present in propolis played a great role in its immunomodulatory properties [45]. All propolis had strong antioxidant activity due to their contents of phenols and flavonoids which increased the cellular immune response [46]. Active flavonoids and cinnamic acid derivatives were responsible for the anti-inflammatory activity of propolis [47], [48], [49], and [50]. Propolis provided beneficial effect on human health, due to its antimicrobial, antiviral, and antioxidant properties, it was widely used in human and veterinary medicine. It entered in manufacturing of cosmetics, medication for cold syndrome, and flu-like infections, treatment of wounds, burns, and acne. It was commercially available in the form of capsules, creams, mouthwash solutions, toothpaste, and, throat lozenges [27].

\section{il. Material and Method}

Chemicals: Aluminum chloride (AlCl3) came from Guangdong Guanghua Sci-Tech Co. Ltd., Shantou,
Guangdong, China, and manufactured by Yueyang Jiazhiyuan Biological Co. Ltd., China.

The dose of aluminum chloride was $80 \mathrm{mg} / \mathrm{kg}$. orally, daily, for six weeks [51].

An ethanol extract of propolis came from Boiron et Cie, Lyon, France.

The dose of the ethanol extract of propolis was $200 \mathrm{mg} / \mathrm{kg}$. orally, daily, for six weeks [52].

Experimental design: Sixty male rats of proven fertility divided into three groups.

Group l: Control group, rats received $2.0 \mathrm{ml}$. distilled water orally, daily, for six weeks.

Group II: Treated group, rats received aluminum chloride $80 \mathrm{mg} / \mathrm{Kg}$. Orally, daily, for six weeks, it was 6 $\mathrm{mg}$. Dissolved in $1.0 \mathrm{ml}$. Distilled water.

Group III: Treated group, rats received aluminum chloride as the same dose, root and period for group II, and $200 \mathrm{mg} / \mathrm{kg}$. Ethanol extract of propolis, orally, daily, for six weeks, it was about $40 \mathrm{mg}$. Dissolved in $1.0 \mathrm{ml}$. Distilled water. After the designed period, the testes were dissected out, trimmed off the attached tissues. Specimens of the testes fixed immediately in 10\% buffered formalin for histological study.

For Histopathological and Ultrastructural Examination: According to Bancroft and Gamble [53], tissues were taken from testes of rats were cut and immediately fixed into $10 \%$ formaldehyde saline. Tissues were processed for the preparation of paraffin blocks (paraffin method). Sections were cut by rotatory microtome and mounted on glass slides. The sections stained by conventional Hematoxylin and Eosin (H\&E), PAS, and Mallory stain, and examined by light microscope.

For the ultrastructural examination: An adjacent section of testis was removed and placed in $0.1 \mathrm{M}$ cacodylate buffer containing 3\% glutaraldehyde for electron microscopy. After fixation, sections were dehydrated in a series of ethanol rinses, cleared with propylene oxide, and embedded in Epon. (Epon or Epon-Araldite mixtures are the most widely used resins for electron microscopy.) The sections were evaluated using a transmission electron microscope (Joel 1200 Ex-II). [53].

\section{Results}

I Histological study

Group I: Control group.

The seminiferous tubules were well circumscribed with a clear basement membrane. The germ cells arranged in multiple layers with the sperms occupied the lumen. The interstitial tissue filled the spaces between the seminiferous tubules, which contained blood vessels, and the interstitial cells of Leydig, which appeared in groups of polyhedral cells (Fig.1-A). The Mallory stain showed the red interstitial 
tissue and the normal thickness of the tunica albuginea (Fig.2-A). The PAS stain showed normal thickness and regular pattern of the basement membrane (Fig.3-A).

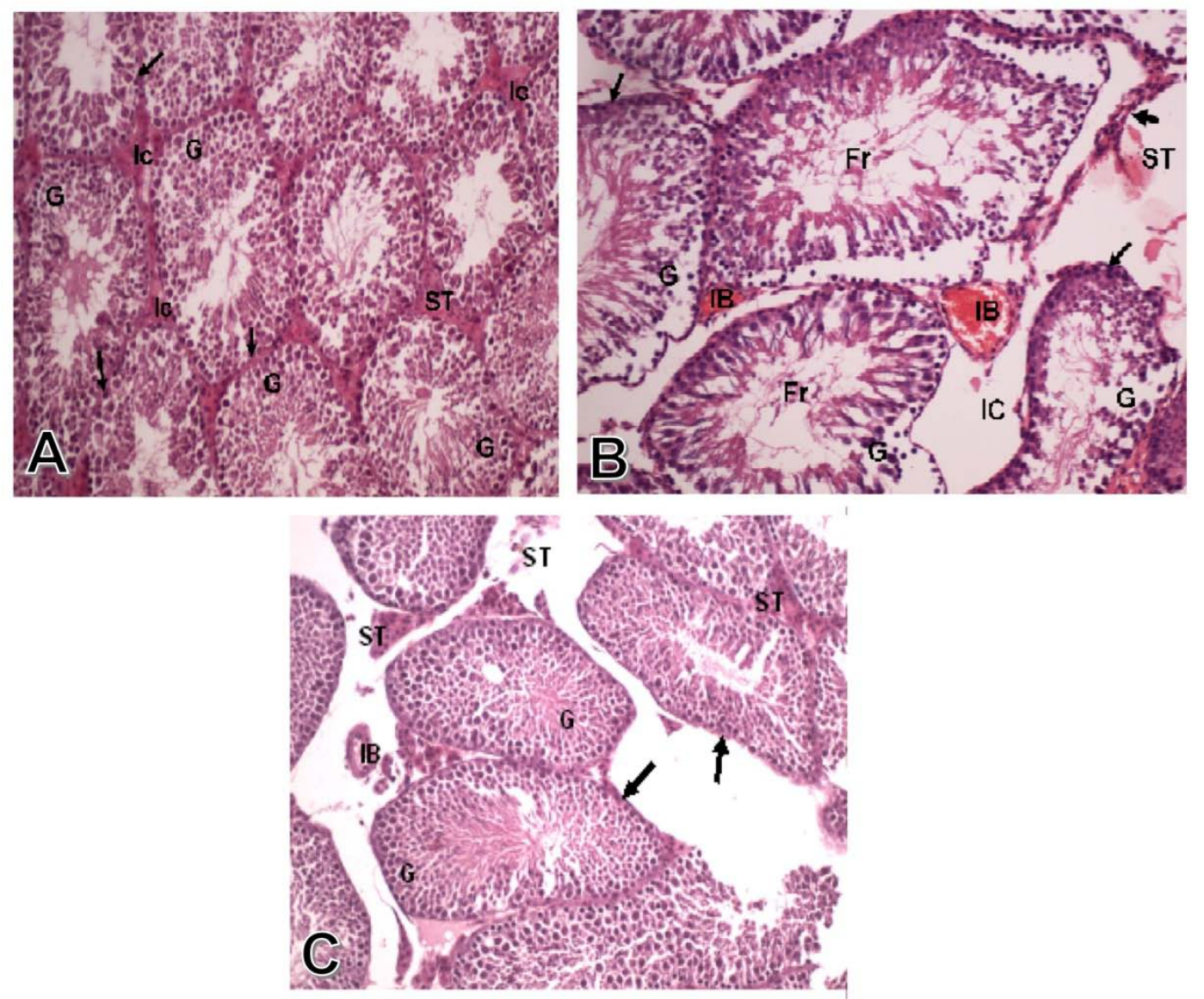

FIG. 1: (A) Photomicrograph of transverse section of testis of a control rat, showing the different stages of spermatogenic cells $(G)$ the seminiferous tubules with thin normal basement membrane (arrow), and the interstitial cells (ST). (H\&E X 250). (B) Photomicrograph of transverse section of testis of the treated group with alumimium chloride, showing marked degeneration and necrosis of germ cells $(\mathrm{G})$ lining of the seminiferous tubules with thick basement membrane (arrows), and fragments of germ cells ( $\mathrm{Fr}$ ) within the lumen of seminiferous tubules. There are also edema of interstitial cells (IC), and congestion of interstitial blood vessel (IB). (H\&E X 250). (C) Photomicrograph of transverse section of testis of the treated group with alumimium chloride, and propolis, showing nearly normal histological pattern in the germ cells $(G)$ lining the seminiferous tubules with normal basement membrane of that tubules (arrows), as well as normal interstitial cells of Leydig (ST) and no congestion of interstitial blood vessels (IB). (H\&E X250)

Group II: Treated with aluminum chloride.

Some of the seminiferous tubules showed marked degeneration and necrosis of the germ cells lining of the tubules. The degenerated tubules showed thick basement membrane and fragments of germ cells in the center of the tubules. There was also edema between the interstitial cells and congestion of interstitial blood vessel (Fig.1-B). There was some fibrosis of the interstitial tissue which appeared blue with Mallory stain (Fig.2-B). There was a decreased PAS reaction in the markedly degenerated germ cells lining the seminiferous tubules, and the interstitial cells (Fig 3-B) 

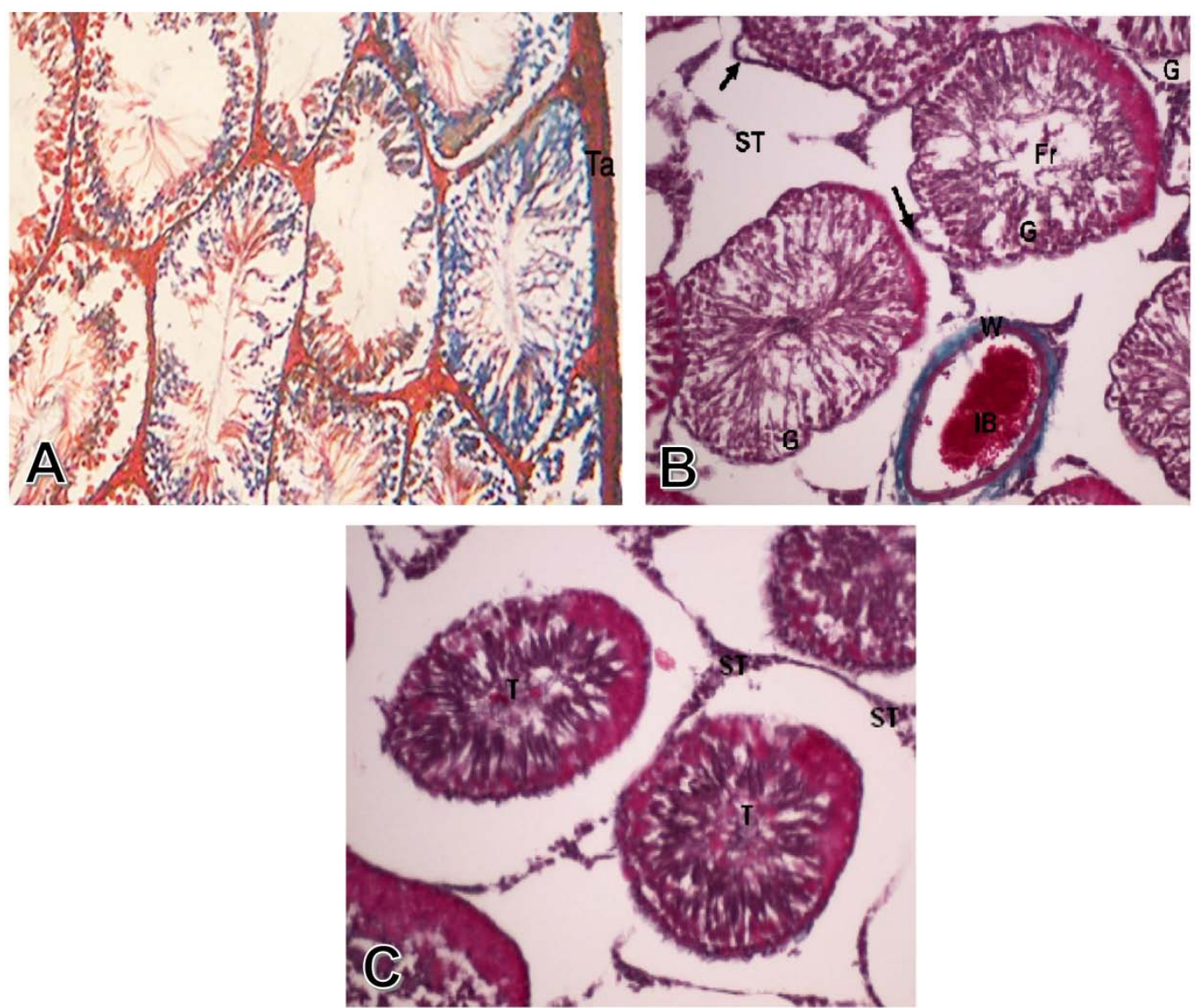

FIG. 2: (A) A photomicrograph of a transverse section of a control rat testis showing normal thickness of tunica albuginea (Ta).(Mallory X250) (B) Photomicrograph of transverse section of testis of the treated group with alumimium chloride, showing congestion of interstitial blood vessel (IB) with necrotic wall (W), as well as degeneration and necrosis of germ cells $(G)$ lining the seminiferous tubules with fragments of germ cells $(F r)$ and thickening of tubules basement membranes (arrows). (Mallory X250) (C) Photomicrograph of transverse section of testis of The group treated with alumimium chloride, and propolis, showing normal histological pattern of seminiferous tubules (T) and normal interstitial cells (ST). (Mallory X250).

Group III: Treated with propolis with concomitant administration of aluminum chloride.

The testis of rats treated with aluminum chloride and propolis extract, showed normal histological pattern of the germ cells, basement membrane, and interstitial cells of Leydig, with lack of congestion of interstitial blood vessels (Fig.1-C). The Mallory stain showed normal histological pattern of seminiferous tubules and the interstitial cells (Fig. 2-C). There were marked increase in PAS reaction of the seminiferous tubules components, and the interstitial cells of Leydig (Fig. 3-C). 

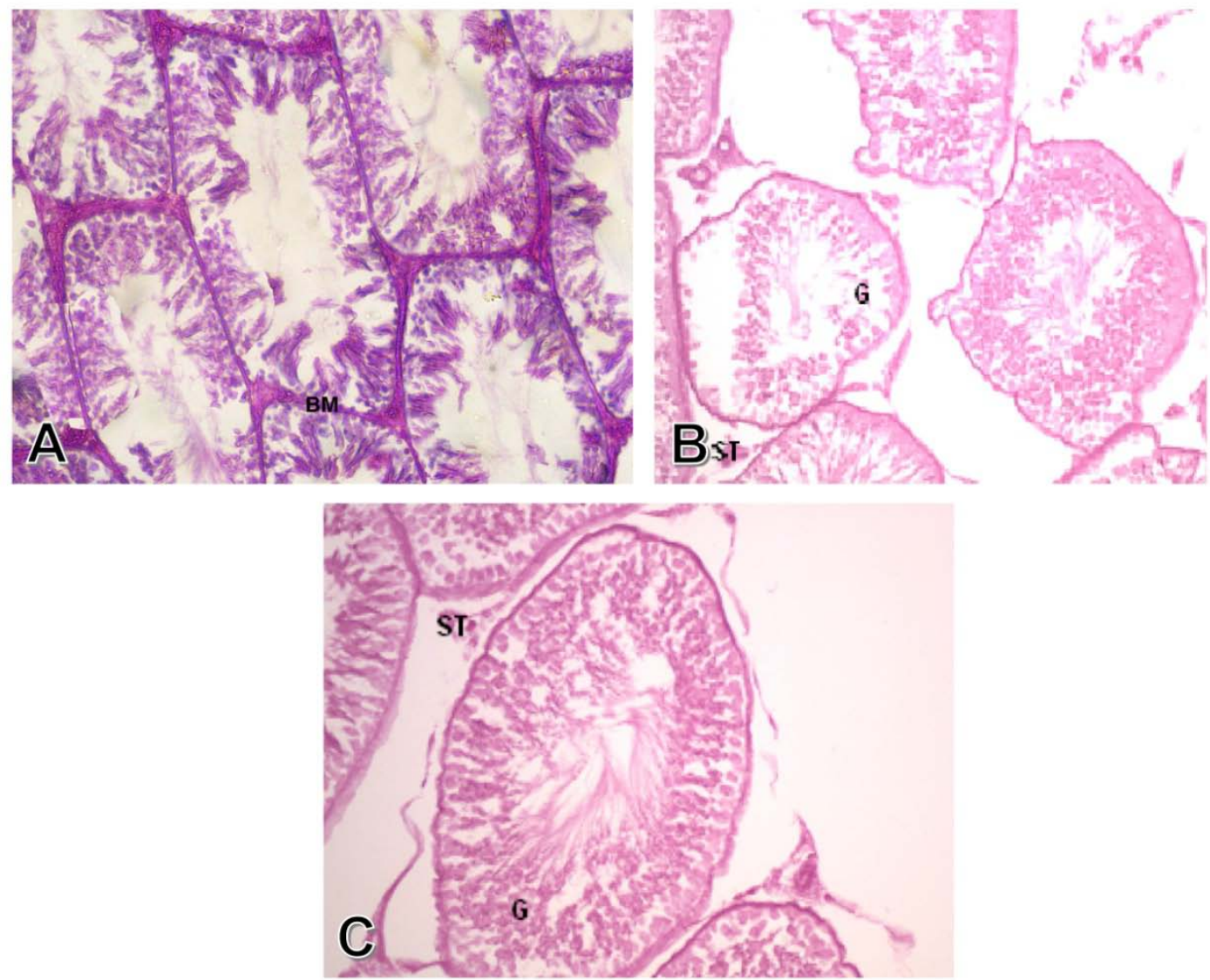

FIG. 3: (A) A photomicrograph of a transverse section of a control rat testis showing normal thickness of the basement membrane (bm) (PAS X250) (B) Photomicrograph of transverse section of testis of the treated group with alumimium chloride, showing a decreased in PAS reaction in the markedly degenerated germ cells (G) lining the seminiferous tubules, as well as decreased PAS reaction of the interstitial cells (ST), (PAS $X$ 250) (C) Photomicrograph of transverse section of testis of the group treated with alumimium chloride, and propolis, showing marked increase in PAS reaction of the seminiferous tubules components including the germ cells $(G)$, and also increase in PAS reaction of interstitial cells of Leydig (ST).(PAS x 250).

\section{Ultrastructure studies}

\section{Group I: Control group.}

The spermatogonia were large diploid cells that lied against the boundary tissue of the seminiferous tubules. The A-type spermatogonia had large pale ovoid nuclei, a scantly granular cytoplasm, and rough endoplasmic reticulum, the mitochondria were spherical or ovoid, and a simple Golgi apparatus. The B-type cells had rounded nuclei, and a granular cytoplasm. Primary spermatocytes had spherical nuclei with fine granular nucleoplasm, scanty cytoplasm, and ovoid mitochondria that aggregated in groups, the Golgi apparatus arranged in few clusters accumulated at one pole of the cell. The secondary spermatocytes were rarely seen, they entered into the second meiotic division producing the spermatids. The early spermatids were rounded cells with large spherical nuclei that contained clumps of chromatin in a lightly stained cytoplasm, the endoplasmic reticulum had flattened vesicles, the mitochondria aggregated at the periphery of the plasma membrane. The cytoplasm of Sertoli cells extended from the basal lamina to the lumen of the seminiferous tubules. The nucleus was enfolded and the cytoplasm contained abundant endoplasmic reticulum, ovoid Golgi apparatus and spherical mitochondria (Figs. 4-A1 \& A2). Group II: Treated with aluminum chloride.

The seminiferous tubules, showed cellular alteration of cells than those in the control groups; the tubular membranes were dilated with irregular Sertoli cells, the spermatogonia contained vacuolated cytoplasm and irregular nuclei, the mitochondria were swollen, the Golgi apparatus contained lipid droplets. The spermatid cells were atrophied, with degenerated nuclei and defected acrosomal caps, degenerated mitochondria, and dilated endoplasmic reticulum (Figs. 4-B1 \& B2). 

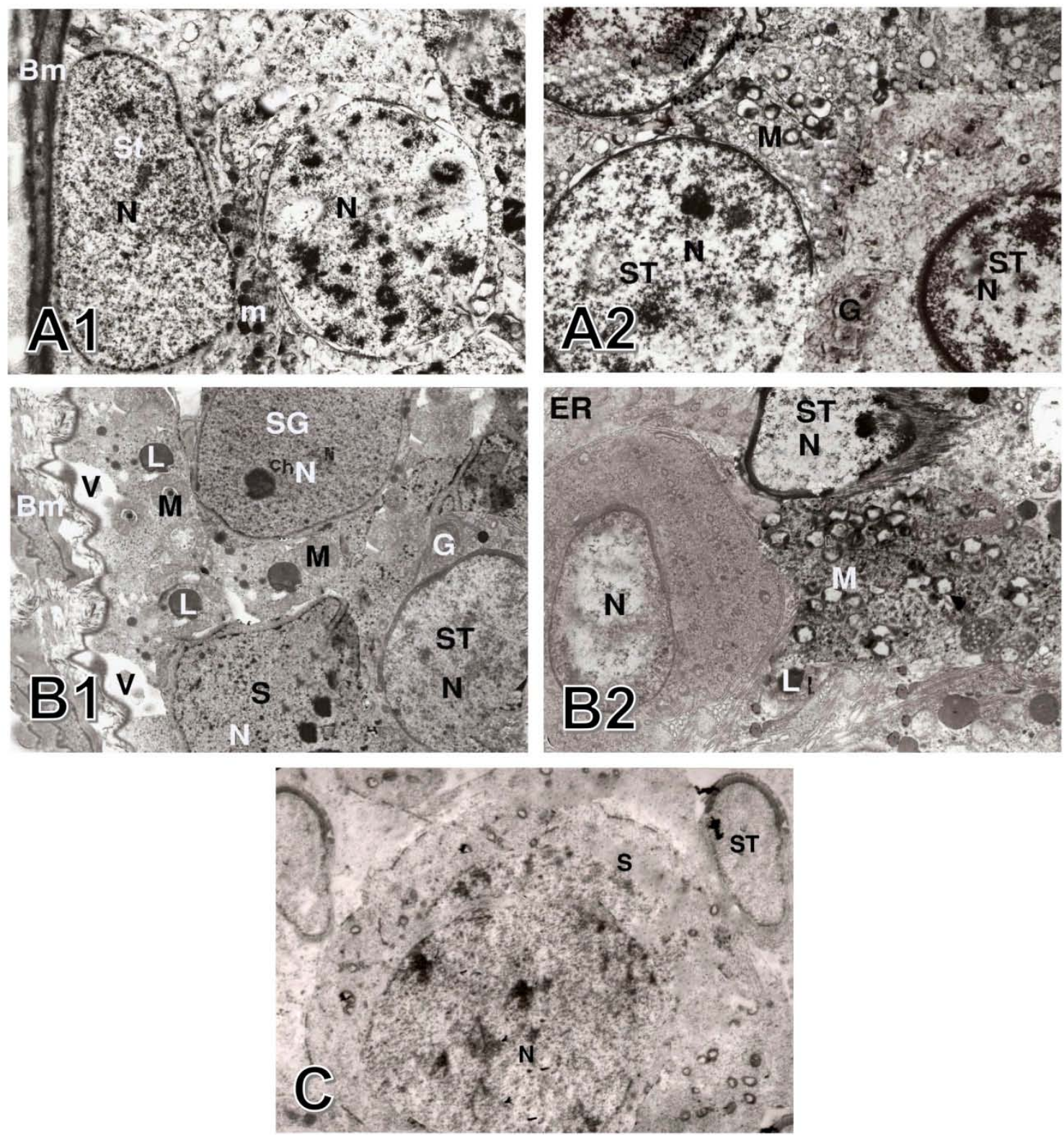

FIG 4: (A1) Photo electron micrograph of the testis of a control rat, showing basement tubular membrane (Bm) A and B types spermatogonia (St), nuclei $(N)$, mitochondria $(m)$.(X120000). (A2) Photo electron micrograph of control rat testis, showing spermatid (ST) and its nucleus (N), mitochondria (M) and Golgi apparatus (G).(X12000). (B1) Photo electron micrograph of testis group treated with aluminum chloride, showing dilated irregular tubular membrane $(\mathrm{Bm})$,Sertoli cell $(\mathrm{S})$, spermatogonia(SG) and early spermatid (ST), and vaculated cytoplasm (V), irregular nuclei (N), swollen mitochondria (M), Golgi apparatus (GA), lipid (L).(X12000). (B2) Photo electron micrographs of rat testis group treated with aluminum chloride, showing degenerative and atrophy of spermatid cells (ST), degenerative nuclei $(\mathrm{N})$, and defects in acrosomal cap formation, degenerated mitochondria $(\mathrm{M})$, dilated endoplasmic reticulum (ER) and cytoplasmic vacuoles (V). (X18000). (C) Photo electron micrograph of rat testis, group treated with aluminum chloride and propolis showing nearly normal spermatid (ST) and secondary spermatocyte (S). (X12000).

Group III: Treated with propolis with concomitant administration of aluminum chloride.

Sections showed no histological changes in the germ cells which, lined the seminiferous tubules with normal basement membrane (Fig. 4-C).
IV. Discussion

Our studies postulated that aluminum chloride exposure caused marked alterations in the histological pattern of the tests which were represented by some of the seminiferous tubules were degenerated, while others appeared necrotic. In addition to degeneration and 
necrosis of germ cells lining of the seminiferous tubules with thick basement membrane and fragments of germ cells in the center of seminiferous tubules. These results parallel to Liobet et al.[21], Guo et al.[23], Fairoze [24], Burdock [25], Yousef et al. [54], and Hala et al.[55], who founded that aluminum chloride caused histopathological lesion in testis as congestion of interstitial blood vessel, marked degeneration and necrosis of the germ cells, absence of spermatic bundles in seminiferous tubules lumen and this might result from degeneration of the spermatogonia which affected spermatogenesis and maturation of sperms, and this supported our results. The role of aluminum chloride in induction of oxidative stress, this toxic effect might result from its ability to bind to cellular DNA, RNA, and proteins, leading to a decrease of their levels in different tissues [56]. And also, the mechanisms that might explain, the degeneration, the coagulative necrosis, and the epithelial sloughing in our results [56], and [57]. According to Fraga et al. [58] and Kumar et al. [59], the presence of interstitial edema in our results might result from the oxidative damage of capillaries endothelial cells through interference with their membranes, which increased their permeability, the increase in permeability and edema might also occur in inflammatory responses due to the liberation of inflammatory mediators from the degenerated and the necrotic parenchymatous cells, and this might explain inflammatory cells infiltration within testicular parenchyma in our results. Our results showed some fibrosis of the interstitial tissue in the markedly degenerated germ cells lining the seminiferous tubules, as well as decreased PAS reaction of the interstitial cells these findings were in agreement with the results of Chinoy et al. [60] who reported profound disorders in carbohydrate metabolism, follow aluminum chloride toxicity. The degeneration and atrophy of spermatid cells, revealed in the present study agreed with the results obtained by Libet et al. [21] and Guo et al. [23]; who found that there was necrosis in the spermatocytes and spermatids after administration of aluminum nitrite to mice, and the gonadal toxicity of rats exposed to, aluminum chloride, which recorded by Alfrey [61], Krasovskii et al. [62], and Alfrey et al. [63]. In the present study, the pathological changes demonstrated in testicular ultrastructure as irregular Sertoli cell, vacuolated cytoplasm and defected spermatogonia after administration of aluminum chloride were in agreement with Khattab [22], and Kamboji and Kar [64], who reported that, the seminiferous tubules were shrunken with spermatogenic arrest at the primary spermatocytes or spermatogonia stages with the treatment by aluminum sulfate. In the present study, some pathological changes in early spermatid with vacuolated cytoplasm and irregular nuclei after administration of aluminum chloride were in agreement with the work of Mayyas, et al. [65], who reported destruction of the seminiferous tubules with large necrotic areas and degenerated cells. Our present study showed no histological changes in the germ cells which line the seminiferous tubules as well as normal interstitial cells of Leydig with lack of congestion of interstitial blood vessels in the testis of rats treated with aluminum chloride with the concomitant treatment with propolis extract, these results agreed with Hasan et al. [66], who reported that the treatment with propolis antagonized aluminum chloride toxicity on liver and testis. The antioxidant property of propolis responsible for its protective effect in our results agreed with Chang et al. [67], Gómez-Caravaca et al. [68], and Mokhtar et al. [69] who reported that, propolis antagonized the harmful reproductive toxicity of aluminum chloride on testis. Propolis reduced the oxidative stress, apoptosis, and necrosis induced by aluminum chloride on the testes seen in the results approved by El Masry et al. [70], and Hasan et al. [66]. In the present study, co-administration of propolis practically prevented most of the toxic effects of aluminum chloride on the testis, these results agreed with Alyane et al. [71] who reported that pretreatment of rats with propolis extract reduced the peroxidative damage in the mitochondria as reducing both of mitochondrial malondialdehyde formation and the amplitude of mitochondrial swelling.

\section{Conclusion}

Our results demonstrated that the aluminum chloride induced toxic structural changes in the rat's testicular tissues, which could be improved by the protective effect of propolis supplement. These results validate the hypothesis that the testicular toxicity of aluminum chloride modulated by propolis supplementation.

\section{References Références Referencias}

1. Nadia Hichem, Michèle El May, Nizar Laadhari, Ali Mrabet and Rafik Gharbi Effect of Chronic Administration of Aluminum Trichloride on Testis among Adult Albino Wistar Rats. J Cytol Histol 2013, 4:5 DOI: 10.4172/2157-7099.1000195.

2. Rajeswari TR, Sailaja N (2014) Impact of heavy metals on environmental pollution. J Chem Parmacol Sci 3: 175-181.

3. R. A. Yokel and P. J. McNamara, "Aluminum toxicokinetic: an updated mini-review," Pharmacology and Toxicology, vol. 88, no. 4, pp. 159-167, 2001.

4. C.D. Hewitt, J. Savory, and M.R. Wills, "Aspects of aluminum toxicity," Clinics in Laboratory Medicine, vol. 10, no. 2, pp. 403-422, 1990.

5. Yousef, M. I. Aluminium induced changes in hematobiochemical parameter, lipid peroxidation and enzyme activities of male rabbits: protective role of ascorbic acid. Toxicol.199:47-57 (2004). 
6. Grams. G. W. Aluminium compounds: aluminium halides and aluminium nitrate: aluminium chloride. In: Kirk_Othmer encyclopedia of chemical technology. 4th ed. Vol 2. John Wiley and Sons: 281-288 (1992).

7. Cannata, J., Briggs, J., Junor, R. and Fell, S. Aluminium hydroxide intake real risk of aluminium toxicity. Brit. Med. J. 286: 1937-1938. (1983). ,

8. Lione, A. Aluminium toxicity and aluminium containing medication. J. Pharmacol. Therapy, 29: 255-285. (1985).

9. Kachny, W., Hegg, A. and Alfrey, A. Gastrointestinal absorption of aluminium from aluminium containing antacids. New Engl. J. Med. 296: 1389-1390. (1997).

10. ATSDR (Agency for Toxic Substances and Disease Registry). Toxicological profile for aluminium. U.S. Department of Health and Human Services. Public Health Service (1990).

11. Ochmanski, W. and Barabasz, W. Aluminium occurrence and toxicity for organisms. Przegl. Lek. 57:665-668 (2000).

12. Yousef, M. I., El_Morsy, A. M. and Hassan, M. S. Aluminium induced deterioration in reproductive performance and seminal plasma biochemistry of male rabbits: protective role of ascorbic acid. Toxicology 215 (1-2): 97-107 (2005).

13. Graves, A. B., White, E., Koespsell, T. D., Relfler, B. V., Belle, G. V. and Larson, E, B. The association between aluminium containing products and Alzheimer`s disease. J. Clin. Epidemiol. 43:35-44 (1990).

14. World Health Organization (Geneva). Environmental health criteria 194: Aluminium. Printed in Finland 97/PLL/11539- Vammada 5000: WHO, p 1-282 (1997).

15. Yousef, M. I., Kamel, K. L., El Demerdash, F. M. "An in vitro study on reproductive toxicity of aluminium chloride on rabbit sperm: the protective role of some antioxidants". Toxicology 239(3): 213-223 (2007)

16. Chinoy, N. J., Bhattacharya, S. E. Effect of single dose of aluminium chloride on some reproductive organs and fertility in male mice. India. J. Environ. Toxicol. 6: 10-13 (1996).

17. Chinoy, N. J., Bhattacharya, S. E. Effects of chronic administration of aluminium chloride on reproductive functions of testis and some accessory sex organs of male mice. India. J. Environ. Toxicol. 7:1217 (1997).

18. Bataineh, H., Al- Hamood, M. H. and Elbetieha A. M. Assessment of aggression, sexual behavior and fertility in adult male rat following long - term ingestion of four industrial metals salts. Hum. Exp. Toxicol. 17 (10): 570-576 (1998).

19. Mayyas, I., Elbetieha, A. and Khamas, W. A. Evaluation of reproductive and fertility toxic potentials of aluminium chloride on adult male mice. Journal of animal and Veterinary Advances. 4(2): 224: 233 (2005).

20. Malekshah, A. K., Torabizadeh, Z. and Naghshwar, $F$. Developmental toxicity of aluminium from high doses of ALCL3 in mice. The journal of Applied Research. Vol. 5 (4): 575-579. (2005).

21. Liobet, J., Colomina, M., Sirvent, J. Domingo, J. and Corbella, J. Reproductive toxicology of aluminium in male mice. Fundam. Appl. Toxicol. 25 (1): 45-51 (1995).

22. Khattab, F. K. I. Histological and ultrastructural studies on the testis of rat after treatment with aluminium chloride. Australian Journal of basic and applied Sciences 1(1): 63-72 (2007).

23. Guo, C., Huang, C., Chiou, y. and Hsu, G. Alteration of trace element distribution and testis ACE activity in mice with high peritoneal aluminium. J. Biol. Trace. Elem. Res. 86(2): 145-157 (2002).

24. Fairoze Khattab I. Khattab. "Histological and Ultrastructural Studies on the Testis of Rat after Treatment with Aluminium Chloride" Australian Journal of Basic and Applied Sciences, 1(1): 63-72, 2007.

25. G. A. Burdock, "Review of the biological properties and toxicity of bee propolis (propolis)," Food and Chemical Toxicology, vol. 36, no.4, pp. 347-363, 1998.

26. V.S. Bankova, S.L. De Castro, and M.C. Marcucci, "Propolis: recent advances in chemistry and plant origin," Apidologie, vol. 31, no.1, pp.3-15, 2000.

27. Vijay D. Wagh "Propolis: A Wonder Bees Product and Its Pharmacological Potentials" Hindawi Publishing Corporation Advances in Pharmacological Sciences" Volume 2013, Article ID308249,11pages http://dx.doi.org/10.1155/2013/ 308249

28. G. A. Burdock, "Review of the biological properties and toxicity of bee propolis (propolis)," Food and Chemical Toxicology, vol. 36, no. 4, pp. 347-363, 1998.

29. Y. K. Park, S. M. Alencar, and C. L. Aguiar, "Botanical origin and chemical composition of Brazilian propolis," Journal of Agricultural and Food Chemistry, vol. 50, no. 9, pp. 2502-2506, 2002.

30. P. G. Pietta, C. Gardana, and A.M. Pietta, "Analytical methods for quality control of propolis," Fitoterapia, vol. 73, no.1, pp. S7- S20, 2002.

31. N. Kumar, M. K. K. Ahmad, R. Dang, and A. Husain, "Antioxidant and antimicrobial activity of propolis from Tamil Nadu zone," Journal of Medicinal Plants Research, vol. 2, no. 12, pp. 361-364,2008.

32. A. Ugur and T. Arslan, "An in vitro study on antimicrobial activity of propolis from Mugla province of Turkey," Journal of Medicinal Food, vol. 7, no.1, pp. 90-94, 2004. 
33. R. A. Laskar, I. Sk, N. Roy, and N. A. Begum, "Antioxidant activity of Indian propolis and its chemical constituents," Food Chemistry, vol. 122, no.1, pp. 233-237, 2010.

34. J M Grange MSc MD R W Davey M F Hom, "Antibacterial properties of propolis (bee glue)", Journal of the Royal Society of Medicine Volume 83 March 1990.

35. A. Selvan, R. Singh, and D. Prabhu, "Research article: antibacteria activity of bee propolis against clinical strains of Streptococcus mutants and synergism with chlorhexidine," International Journal Pharmaceutical Studies Research, vol. 2, pp. 85-90, 2011.

36. A. N. Koc, S. Silici, F. Kasap, H. T. H "ormet-"Oz, H. Mavus Buldu, and B. D. Ercal, "Antifungal activity of the honeybee products against Candida spp. and Trichosporon spp," Journal of Medicinal Food, vol.14, no. 1-2, pp. 128-134, 2011.

37. A. C. P. Oliveira, C. S. Shinobu, R. Longhini, S. L. Franco, and T. I. E. Svidzinski, "Antifungal activity of propolis extract against yeasts isolated from onychomycosis lesions," The Memorias do Instituto Oswaldo Cruz, vol.101, no. 5, pp. 493-497, 2006.

38. A. N. Koc, S. Silici, F. Multu-Sariguzel, and O. Sagdic, "Antifungal activity of propolis in four different fruit juices," Food Technology and Biotechnology, vol. 45, pp. 57-.61, 2007.

39. K. F. D. Dota, M. E. L. Consolaro, T. I. E. Svidzinski, and M. L. Bruschi, "Antifungal activity of Brazilian propolis micro particles against yeasts isolated from vulvovaginal candidiasis," Evidence-Based Complementary and Alternative Medicine, vol. 2011, Article ID 201953, 8 pages, 2011.

40. S. L. De Castro, K. Salom ao, E. M. De Souza, A. Henriques-Pons, and H. S. Barbosa, "Brazilian green propolis: effects in vitro and in vivo on Trypanosoma cruzi," Evidence-Based Complementary and Alternative Medicine, vol. 2011, Article ID 185918, 11 pages, 2011.

41. D. Torres, I. Hollands, and E. Palacios, "Effect of an alcoholic extract of propolis on the in vitro growth of Giardia lamblia720," Journal of Veterinary Science, vol.21, no.1, pp.15-19, 1990.

42. A. P. Dantas, B. P. Olivieri, F. H. M. Gomes, and S. L. de Castro, "Treatment of Trypanosoma cruziinfected mice with propolis promotes changes in the immune response," Journal of Ethnopharmacology, vol.103, no.2, pp.187-193, 2006.

43. N. Ořsoli'c, A. B. 'Saranovi'c, and I. Ba' si'c, "Direct and indirect mechanism(s) of antitumour activity of propolis and its polyphenolic compounds," Planta Medica, vol. 72, no. 1, pp. 20-27, 2006.

44. A. Cuesta, A. Rodr'ıguez, M. 'A. Esteban, and J. Meseguer, "In vivo effects of propolis, a honeybee product, on gilt head seabream innate immune responses," Fish and Shellfish Immunology, vol.18, no.1, pp. 71-80, 2005.

45. S. M. Sayed, G. A. Abou El-Ella, N. M. Wahbaetal. , "Immune defense of rats immunized with fennel honey, propolis, and bee venom against induced staphylococcal infection," Journal ofMedicinalFood, vol. 12, no. 3, pp. 569-575, 2009.

46. G. Fischer, F. R. Conceic, ao, F. P. L. Leite et al., "Immunomodulation produced by a green propolis extract on humoral and cellular responses of mice immunized with SuHV-1," Vaccine, vol.25, no.7, pp.1250-1256, 2007.

47. M. F. Osman and E. A. Taha, "Anti-oxidant activity of water extract of propolis from different regions in Kafr El-Sheikh Governorate," Alexandria Journal of Food Science and Technology, vol.1, pp.83-89, 2008.

48. E. C. D. Almeida and H. Menezes, "Antiinflammatory activity of propolis extracts: a review 2104," Journal of Venomous Animals and Toxins, vol.8, pp. 191-212, 2002.

49. F. Borrelli, P. Maffia, L. Pintoetal., "Phytochemical compounds involved in the anti-inflammatory effect of propolis extract," Fitoterapia, vol.73, no.1, pp. S53-S63, 2002.

50. K. DuToit, S. Buthelezi, and J. Bodenstein, "Antiinflammatory and antibacterial profiles of selected compounds found in south African Propolis," South African Journal of Science, vol. 105, no. 11-12, pp. 470-472, 2009.

51. Entissar, M. Abdul-Rasoul. Nathem, A. Hassan. Karam, H. Al-Mallah. Effect of Aluminium Chloride on Sexual Efficiency in Adult Male Rats. J. Edu. \& Sci., Vol. (22), No. (4) 2009.

52. Hamid Reza Sameni, Parisa Ramhormozi, Ahmad Reza Bandegi, Abbas Ali Taherian, Majid Mirmohammadkhani, Manouchehr Safari "Effects of ethanol extract of propolis on histopathological changes and anti-oxidant defense of kidney in a rat model for type 1 diabetes mellitus" J Diabetes Investig Vol. 7 No. 4 July 2016.

53. Bancroft, J.D. and Gamble, M. (2002): Theory and Practice Histological Techniques, 5th ed., Churchill Livingstone. New York, Edinburgh and London, pp. 126 and 173-175.

54. Yousef, M.I., Kamel, K.L., ElGuendi, M.I. and ElDemerdash, F.M. (2007): An in vitro study on reproductive toxicity of aluminium chloride on rabbit sperm: The protective role of some antioxidants. Toxicology, 239: 213-223.

55. Hala, A.H. Khattab, Inas, Z.A. Abdallah and Gehan, M. Kamel. (2010): Grape seed extract alleviate reproductive toxicity caused by aluminium chloride in male rats. Journal of American Science; 6(12): 1200-1209. 
56. Fyiad, A. A. Aluminium toxicity and oxidative damage reduction by melatonin in rats. J Appl Sc Res; 3: 1210-1217 (2007).

57. Han, J. and Dunn, M. A. Effect of dietary aluminium on tissue nonheme iron and ferritin levels in the chick. Toxicology 142: 97109 (2000).

58. Farga, C. G., Oteiza, P. I. and Golub, M. S. Effects of aluminium on brain lipid peroxidation. Toxicol; 51 : 213-219 (1999).

59. Kumar, V., Cortan, R. and Robins, M. D. Acute and chronic inflammation. Basic pathology. 6th ed. WB Saunders Company. Philadelphia: 25-46 (1997).

60. Chinoy, J., Sorathia, P. and Jhala, D. Flouride + Aluminun induced toxicity in mice testis with giant cells and its reversal by vitamin C. J. Fluride, 38 (2): 109-114 (2005).

61. Alfrey, C., 1984. Aluminium intoxication. New Engl. J. Med., 310: 1113-1114.

62. Krasovskii, G.N., Vasukovich, L.Y., Chariev, O.G., (1979): Experimental study of biological effects of leads and aluminum following oral administration. Environ. Health Perspect. 30, 47-51

63. Alfrey, C., R. Legendre and D. Kaehny, 1976. The dialysis encephalopathy syndrome possible aluminium intoxication. New Engl. J. Med., 294: 184-188.

64. Kamboj, P. and B. Kar, 1964. Antitesticular effect of metallic and rare earth salts. J. Repord Fertil, (7): 21-28.

65. Mayyas, I., A. Elbetieha, W. Khamas and A. Khamas, 2005. Evaluation of reproductive and fertility toxic potentials of aluminium chloride on adult male mice, J. of Anim. \& Vetr. Adv., 4(2): 224233.

66. Hasan Türkeza, Mokhtar I. Yousef, and Fatime Geyikoglu (2010) : Propolis prevents aluminiuminduced genetic and hepatic damages in rat liver Food and Chemical Toxicology Volume 48, Issue 10, October 2010, Pages 2741-2746

67. Chang C, Yang M, Wen H, Chern J (2002): Estimation of total flavonoid content in propolis by two complementary colorimetric methods. J.Food Drug Analaysis, 10: 178-182.

68. Gómez-Caravaca AM, Góomez-Romero M, ArráezRomán D, Segura-Carretero A and FernándezGutiérrez A (2006): Advances in the analysis of phenolic compounds in products derived from bees. J.Pharm. Biomed. Anal., 41: 1220-1234.

69. Mokhtar I. Yousefa, and Afrah F. Salama (2009): Propolis protection from reproductive toxicity caused by aluminium chloride in male rats. Food and Chemical Toxicology Volume 47, Issue 6, June 2009, Pages 1168-1175.

70. El-Masry Thanaa A., Ashraf M Emara and Nagla A El-Shitany (2011): Possible protective effect of propolis against lead-induced neurotoxicity in animal model. Journal of Evolutionary Biology Research Vol. 3 (1), pp. 4-11 January 2011.

71. Alyane M, Benguedouar KEBSA L.W., Boussnane HN, Rouibah $H$ and Lahouel M (2008): Cardioprodective effect and mechanism of action of polyphenols extracted from propolis against doxorubicin toxicity. Pak. J. Pharm. Sci., Vol.21, No.3, July 2008, pp. 201-209

Materials and Methods: A total of 40 male Wistar rats were randomly divided into the following five groups: control, diabetes mellitus, diabetes mellitus with vehicle treatment, diabetes mellitus with propolis treatment (100 $\mathrm{mg} / \mathrm{kg}$ ) and diabetes mellitus with propolis treatment (200 mg/kg). Diabetes mellitus in rats was induced by intraperitoneal injection of streptozotocin $(60 \mathrm{mg} / \mathrm{kg}$ ). Diabetic groups were treated with vehicle or ethanolic extracts of Iranian propolis for 6 weeks. Serum concentration of malondialdehyde, superoxide dismutase and glutathione peroxidase were measured.

EEP at dose levels of $200 \mathrm{mg} / \mathrm{kg}$ bodyweight by oral gavages, daily for 6 weeks.

Hamid Reza Sameni, Parisa Ramhormozi, Ahmad Reza Bandegi, Abbas Ali Taherian 1, Majid Mirmohammadkhani, Manouchehr Safari "Effects of ethanol extract of propolis on histopathological changes and anti-oxidant defense of kidney in a rat model for type 1 diabetes mellitus" J Diabetes Investig Vol. 7 No. 4 July 2016 .

Entissar, M. Abdul-Rasoul. Nathem, A. Hassan. Karam, H. Al-Mallah. Effect of Aluminium Chloride on Sexual Efficiency in Adult Male Rats. J. Edu. \& Sci., Vol. (22), No. (4) $200980 \mathrm{mg} / \mathrm{kg}$ orally by cavage tube for 60 days (6 weeks). 